\title{
Deradelphous Cephalothoracoomphalopagus in kittens - case report
}

\author{
[Cefalotoraconfalopago derafelfo em gatos - relato de caso] \\ V.C.C. Rodrigues ${ }^{1}{ }^{(D)}$, J.B.S. Oliveira ${ }^{2}$, C.M.G. Sousa ${ }^{3}$, S.B. Araújo ${ }^{4}$, \\ D.M. Abreu $^{2}$, S.A.F. Baêta ${ }^{*}$ (D) \\ ${ }^{1}$ Graduate, Universidade Federal do Piauí, Setor de Patologia Animal, Teresina, PI \\ ${ }^{2}$ Graduate, Universidade Federal de Minas Gerais, Escola de Veterinária, Belo Horizonte, MG \\ ${ }^{3}$ Practitioner, Teresina, PI \\ ${ }^{4}$ Veterinary, Universidade Federal do Piauí, Setor de Diagnóstico por imagem, Teresina, PI \\ ${ }^{5}$ Universidade Federal do Piauí, Teresina, PI
}

\begin{abstract}
The present report describes a case of conjoined twins of the cephalo-thoraco-omphalopagus deradelphous type in cats. A feline female was transferred to our veterinary hospital as an emergency for dystocic labor. The stillborn was subjected to radiographic evaluation, and a single skull and two complete distinct vertebral columns were found. Anatomopathological examination revealed that the twins presented the head, chest, and umbilicus as the main points of union and were classified as the cephalo-thoracoomphalopagus type. In addition, the twins had unique and well-developed faces, which allowed them to be classified as deradelphous. This malformation is rare in domestic animals, and to the best of our knowledge, this type has not been reported in felines. Further studies are warranted on this embryonic alteration, primarily because its etiology remains unknown.
\end{abstract}

Keywords: conjoined twins, embryonic duplication, malformation, feline

\section{RESUMO}

O presente relato descreve um caso de gêmeos siameses do tipo cefalotoraconfalopago deradelfo em gatos. Uma fêmea felina foi atendida na emergência do hospital veterinário em trabalho de parto distócico. Os natimortos foram encaminhados para avaliação radiográfica e constatou-se que apresentavam um único crânio e duas colunas vertebrais completas e distintas. $O$ exame anatomopatológico evidenciou que os gêmeos possuíam cabeça, tórax e umbigo como principais pontos de união, sendo classificados como cefalotoraconfalopago. Além disso, os gêmeos apresentaram face única e bem desenvolvida, o que permitiu classificá-los como deradelfos. Esse tipo de malformação é raro em animais domésticos, e não foi encontrado nenhum trabalho em felino com a mesma classificação do presente relato. Há necessidade de mais estudos sobre essa alteração embrionária, pois a etiologia do processo ainda não foi esclarecida.

Palavras-chave: gêmeos siameses, duplicação embrionária, malformação, felino

\section{INTRODUCTION}

Cephalo-thoraco-omphalopagus is an extremely rare type of twins joined by the head, thorax, and umbilicus but with distinct vertebral columns, limbs, and pelvis (Koreti et al., 2014). In the deradelphous type, conjoined twins are united by the head and present a single, well-formed face (Grassi et al., 2004).

*Corresponding author: silviavet2010@gmail.com Submitted: March 15, 2021. Accepted: May 24, 2021.
Twins that originate from the division of a single zygote are called monozygotes, which are genetically identical and may share some or all fetal membranes. They are of the same sex and appear physically identical (Vaquer and Hadjantonakis, 2013).

Monozygotic twins can be born united, called conjoined twins, and they represent an embryonic malformation in which two complete or 
incomplete bodies are connected by one or more anatomical sites (Spencer, 2000). The frequency of conjoined twins in animals remains unknown because of the scarcity of studies; however, single reports are available in cats (Mazzullo et al., 2009; Seavers, 2009), wild felines (Kompanje and Hermans, 2008), dogs (Nottidge et al., 2007; Moura et al., 2017), goats (Binanti, Riccaboni, 2012), and lambs (Lanteri et al., 2013).

The classification of conjoined twins is based on the most prominent site of connection and pagus - the Greek term for "fixed" or "joined" twins. According to the literature, eight types of twins are recognized: cephalopagus, joined by the head; craniopagus, joined by any area of the skull without the involvement of other head sites; thoracopagus, joined by the thorax; rachipagus; with a single spine; omphalopagus, with a single umbilicus; ischiopagus, joined by the hip; pygopagus, with a shared sacrococcygeal and perineal region; and parapagus, joined by the lateral body extension (Spencer, 2000).

The connection sites may have different degrees of extension and may occur at a single or multiple anatomical locations, such as in the case of the 1095ephalon-thoraco-omphalopagus type (Koreti et al., 2014). According to the facial position, conjoined twins united by the head are classified into three categories: symmetric or janiceps, when a single head shows composite faces, one on each side; asymmetric or iniop, when a single head has two faces, one being more developed than the other; and deradelphous, when a single head shows a single, well-formed face, as in the present case report (Grassi et al., 2004).

\section{CASUISTRY}

A 2-year-old mixed breed feline female was transferred as an emergency for the labor dystocia of the second kitten to the Veterinary Hospital of the Federal University of Piauí. According to the guardian, one kitten was born at home. During clinical examination, the fetus was observed in the vaginal canal. The fetus was removed through obstetric maneuvers, and they were conjoined twins with a single head, two pelvis, four thoraces, and four pelvic limbs. The malformed kittens died immediately after birth, but the mother recovered.

Radiographic examination of the kittens revealed a single skull, two complete and distinct vertebral columns, and well-developed bones, exhibiting radiopacity as expected for the animals of young age (Figure 1).

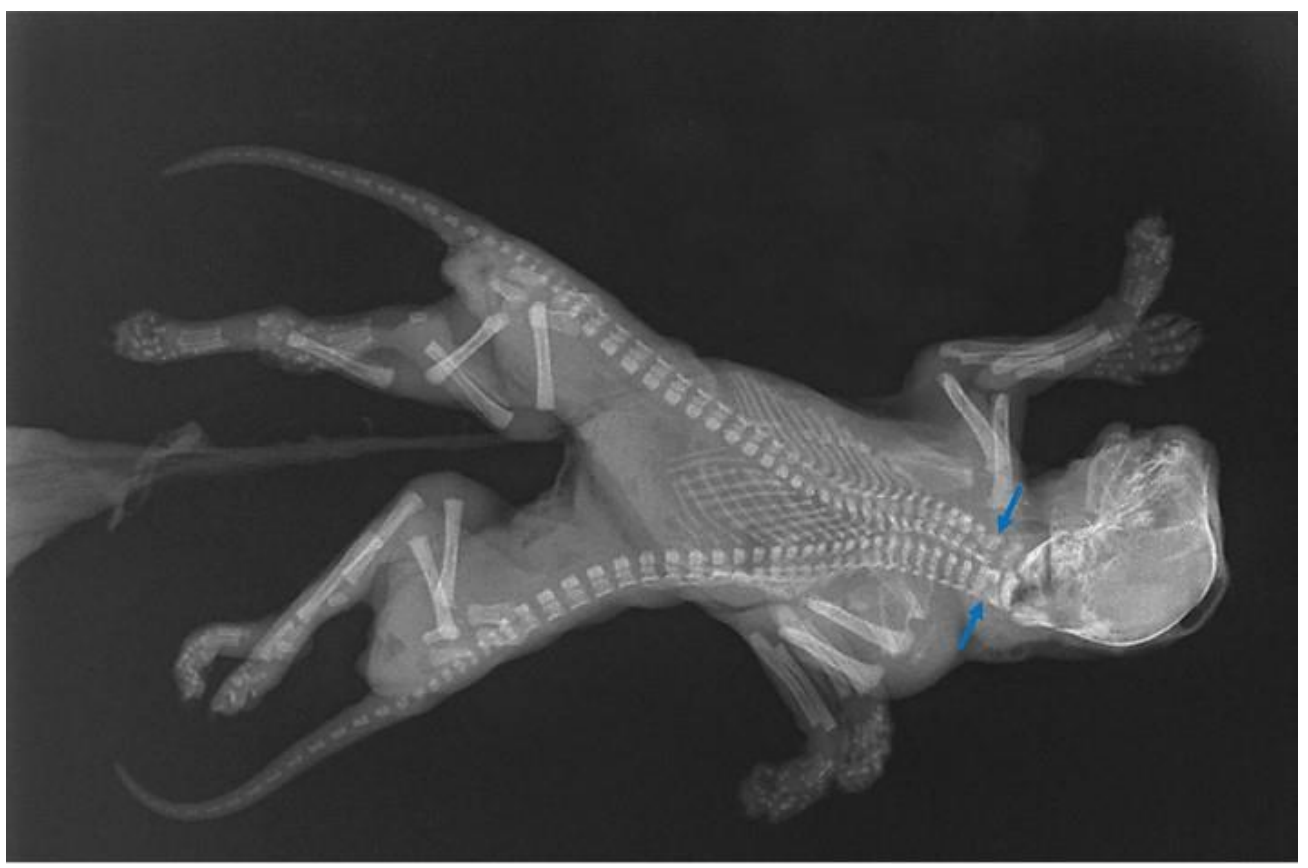

Figure 1. Radiograph of the conjoined twins in the right lateral position. 
Necropsy and photo-documentation of all stages were performed. The twins had a head with a single face, two well-developed eyes, two wellformed nostrils, a lower and an upper cheiloschisis (cleft lip), an oral cavity with two tongues, and two fused palates, both with palatoschisis. There was no fusion of the mandibular arches in the mentonian region, and inferior cheiloschisis was observed. The cats had two pairs of well-developed thoracic limbs, a unique navel, and an umbilical cord connected to the placenta. From the umbilical region, the body was divided into two distinct and well-developed pelvis, each containing a pair of anatomically normal limbs, tail, vulva, and anus. The only malformation observed in the skull was a large foramen magnum, through which both vertebral columns were inserted.

The respiratory system comprised two wellformed nostrils and two nasal cavities, a single trachea, and a pair of morphologically normal lungs. There were two communicating thoracic cavities, one poorly developed and the other well formed, containing the lungs, a single heart, and a diaphragm, which separated the two thoracic cavities from the single abdominal cavity. Of note, despite having two thoracic cavities, the conjoined twins had a single upper and lower respiratory tract, since one of the cavities was hypoplastic and did not contain any organs within.

The digestive system comprised a single esophagus, stomach, small intestine, and cecum. The bifurcation started from the ileocecal region, originating from two distinct large intestines that ended in two distinct rectums and anuses. The liver, pancreas, and spleen were also unique, with normal macroscopic characteristics. The twins had two anatomically well-formed genitourinary systems, each with a pair of kidneys and ureters, urinary bladder, urethra, a pair of ovaries, uterus, vagina, and vulva.

\section{DISCUSSION}

The occurrence of conjoined twins of the cephalothoraco-omphalopagus deradelphous type, as observed in the present case report, is extremely rare in animals, and thus far, only one case in sheep has been reported (Lanteri et al., 2013). Twins joined by the head and thorax are called cephalo-thoracopagus and account for $11 \%$ of all conjoined twins in humans. Meanwhile, twins joined by the umbilical cord, as observed in the present report, are called cephalo-thoracoomphalopagus, and this type represents an extremely rare malformation in humans (Koreti et al., 2014).

To the best of our knowledge, there has been no report of feline cephalon-thoraco-omphalopagus deradelphous twins, as described in the present study. Cases of feline and canine cephalonthoracopagus deradelphous twins, with two distinct umbilical cords, have been reported (Mazzullo et al., 2009; Moura et al., 2017).

The precise mechanism underlying the formation of conjoined twins remains largely unclear. Specific changes during the development of monozygotic twins have been attributed to this malformation, and two theories have been proposed in this regard: fission and fusion. The fission theory is the most commonly accepted explanation, which suggests that incomplete or late division of the monozygotic disc leads to this malformation. According to the fusion theory, the union of two initially separate monozygotic embryonic discs leads to this malformation (Spencer, 2000).

In both humans and other animals, the causes of developmental anomalies are multifactorial, being linked to genetic and environmental factors, such as infectious diseases, teratogenic substances, mineral and vitamin deficiency, radiation exposure, hormonal and pharmacological factors, or a combination of several of these (Vaquer and Hadjantonakis, 2013). However, the genetic association of the occurrence of conjoined twins has not been reported; therefore, the etiology of this malformation may be related to environmental and external factors (Kaufman, 2004). In the present report, the information on the history of the mother cat was not sufficient to determine the underlying etiology or pathogenesis. 


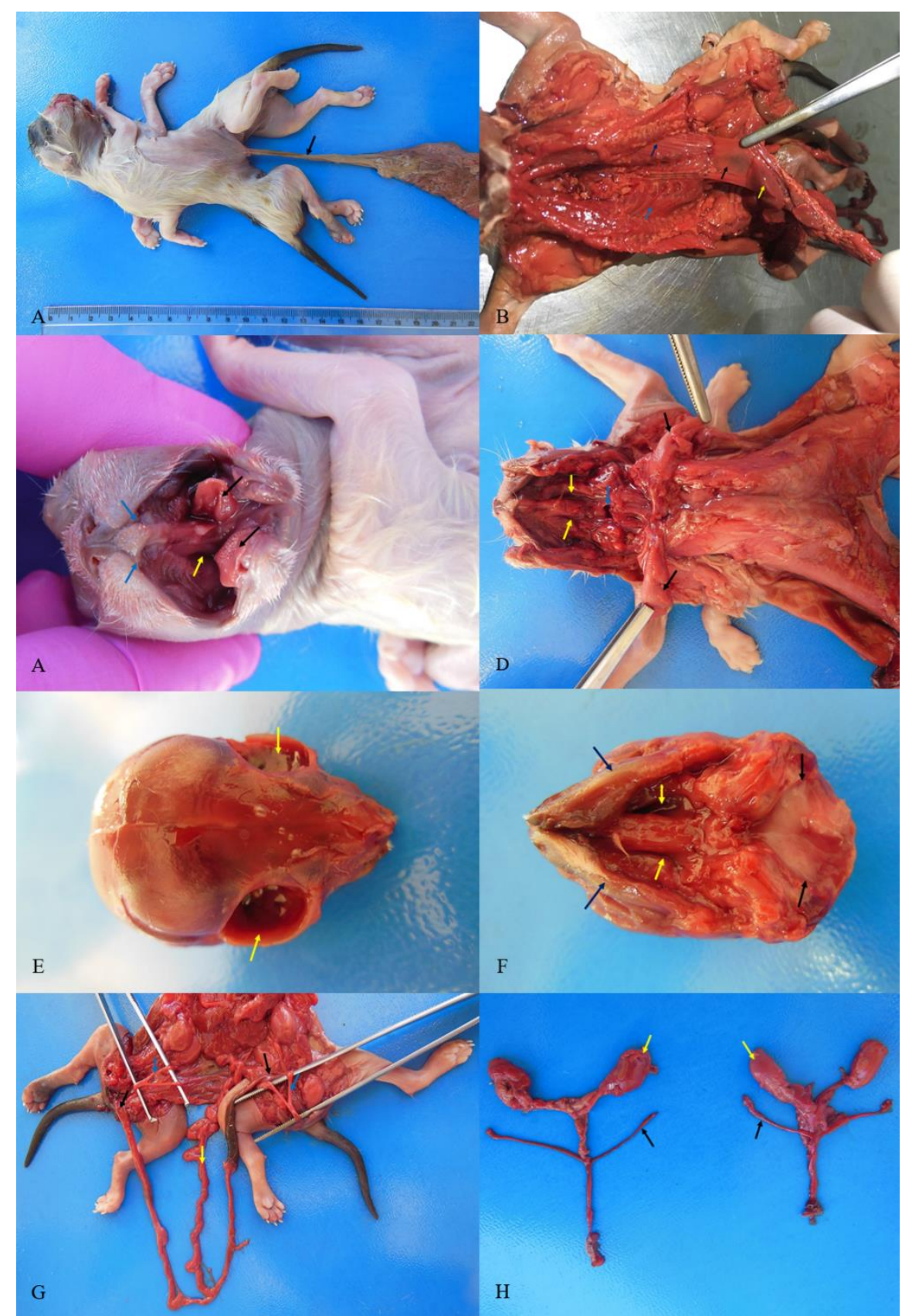

Figure 2. Necropsy and photo-documentation of the conjoined twins. A. Twins in the right lateral position showed two pairs of thoracic and pelvic limbs, a unique umbilical cord (black arrow), and two pelvis. B. Two thoracic cavities, one normal (light blue arrow) and other hypoplasic (dark blue arrow), diaphragm (black arrow), and lungs (yellow arrow). C. Single-faced head with upper cheiloschisis (light blue arrow), oral cavity with two tongues (black arrow), and two fused palates with palatoschisis (yellow arrow). D. Twins in the dorsal position showing oral cavities with palatoschisis (yellow arrow), foramen magnum (light blue arrow), and two tongues (black arrow). E. Skull with two orbits (yellow arrow). F. Skull in the dorsal position showing mandibular arches (dark blue arrow), palatoschisis (yellow arrow), and foramen magnum (black arrow). G. Twins in the dorsal position showing pelvic and abdominal cavities, uteri (light blue arrow), ovaries (black arrow), and intestines (yellow arrow). H. Genitourinary system with kidneys (yellow arrow) and uteri (black arrow). 
In animal studies, specific drugs administered to gravid females have been linked to the formation of conjoined twins, including dimethyl sulfoxide (DMSO) in hamsters and prochlorperazine in rats. In a previous experiment, exposure of mice to vincristine sulfate, which is a chemotherapeutic agent leading to mitotic inhibition and which is frequently used in veterinary medicine, led to the formation of conjoined twins of the cephalothoracopagus type (Kaufman, 2004).

The prognosis of any type of twins joined by the head and thorax, as in the present case, is extremely unfavorable, as the brain and heart of these individuals are unique, thereby preventing surgical separation. These embryonic malformations are very important because of their association with dystocic births and high fetal mortality, and although it did not occur in the present case, these malformations often result in the death of the mother (Vaquer and Hadjantonakis, 2013).

\section{CONCLUSION}

In the present case report, based on anatomopathological and radiographic examinations, the diagnosis of feline conjoined twins of the cephalon-thoraco-omphalopagus deradelphous type was confirmed.

\section{REFERENCES}

BINANTI, D.; RICCABONI, P. ThoracoOmphalopagus conjoined twins in chamoiscoloured domestic goat kids. Anat. Histol. Embryol., v.41, p.159-162, 2012.

GRASSI, R.; ESPOSITI, V.; SCAGLIONE, M. et al. Multi-detector row CT for depicting anatomic features of cephalothoracopagus varieties: revised approach. Radiographics, v.24, p.21-21, 2004.

KAUFMAN, M.H. The embryology of conjoined twins. Child's Nerv. Syst., v.20, p.508-525, 2004.
KOMPANJE, E.J.O; HERMANS, J. Cephalopagus conjoined twins in a leopard cat (Prionailurus bengalensis). J. Wildl. Dis., v.44, p.177-180, 2008.

KORETI, S.; PRASAD, N.; PATELL, G. Cephalothoracoomphalopagus: a rare type of conjoined twin. J. Clin. Neonatol., v.3, p.47, 2014.

LANTERI, G.; MACRÌ, F.; MARINO, F. et al. A rare case of deradelphus cephalothoracoomphalopagus in lamb. Anat. Histol. Embryol., v.42, p.394-397, 2013.

MAZZULLO, G.; MACRÌ, F.; RAPISARDA, G.; MARINO, F. Deradelphous cephalothoracopagus in kittens. Anat. Histol. Embryol., v.38, p.327329, 2009.

MOURA, E.; THON, B.; PIMPÃO, C.T. Canine conjoined twinning: A pathoanatomical study of a Lhasa Apso symmetrical cephalothoracopagus. Anat. Histol. Embryol., v.46, p.606-610, 2017.

NOTTIDGE, H.O.; OMOBOWALE, T.O.; OLOPADE, J.O.; OLADIRAN, O.O.; AJALA, O.O. et al. A case of craniothoracopagus (monocephalus thoracopagus tetrabrachius) in a dog. Anat. Histol. Embryol, v.36, p.179-181, 2007.

SEAVERS, A.M. Monocephalus dipygus parapagus: a suspected case of complete caudal duplication in a British Blue kitten. J. Feline Med. Surg., v.11, p.330-331, 2009.

SPENCER, R. Theoretical and analytical embryology of conjoined twins: part $\mathrm{I}$ : embryogenesis. Clin. Anat., v.13, p.36-53, 2000.

VAQUER, A.F.; HADJANTONAKIS, A.K. Birth defects associated with perturbations in preimplantation, gastrulation, and axis extension: from conjoined twinning to caudal dysgenesis. Wiley Interdiscipl. Rev. Develop. Biol., v.2, p.427-442, 2013. 